https://doi.org/10.18485/poet_srp_real.2018.ch7

\author{
Милена М. Станковић ${ }^{1}$ \\ Универзитет у Нишу \\ Филозофски факултет
}

\title{
ИНТЕРТЕКСТУАЛНОСТ И ИЛИЈА И. ВУКИЋЕВИЋ
}

Рад се бави природом односа Вукићевићевих уметничких

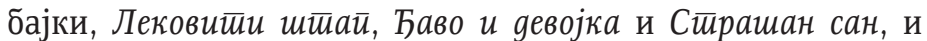
жанрова усмене оријентације. Истраживање ће разматрати проблем жанровске полифоније Вукићевићеве бајке, поступак апсорбовања разногласних семантичко-структурних форми фолклорне литературе - народне гатке, као и новеле и шаљиве приче. Тумачење ће пратити процес трансформације усмене бајке унутар дискурса реалистичке литературе, њену адаптацију у новом књижевном контексту, као и дестабилизацију и пародију. Применом интертекстуалног приступа базираног на теоријским поставкама Зорана Константиновића, показаћемо пут којим је уметничка бајка у доба позног реализма прешла од парадигматичног до гротескно-фантастичног облика.

Кључне речи: Илија И. Вукићевић, уметничка бајка, реализам, усмена књижевност, пародија, интертекстуални приступ

\footnotetext{
${ }^{1}$ milenastankovic1705@hotmail.com
} 
Српски писци прве половине 19. века у своје књижевно стварње избегавали су да уносе елементе чудесног и фантастичног. Ирационални, мистични и окултни елементи јављају се тек у другој половини века и на специфичан начин бивају имплементирани у ткиво српске уметничке приповетке. (Живковић 1977: 233) Међу српским приповедачима 19. века, Грчић први почиње да уноси фантастичне елементе и тиме отвара пут Глишићу, Веселиновићу и Ранковићу, као и другим српским реалистима који су имплементирали фолклорну фантастику у описе сеоског живота.Последње деценије 19. века појавила се уметничка бајка мање познатог српског писца, Илије И. Вукићевића ${ }^{2}$. Вукићевићева уметничка бајка представља стилизацију народне бајке и „носи очевидан печат народске фантастике и значи непосредно настављање оне линије коју је започео Јован Грчић, а коју су продужили Глишић и Веселиновић." (Живковић 1994: 233)

Чињеница да су на формирање поетичког лика српске реалистичке приповетке у великој мери утицали жанровски модели усмене литературе, не представља никакву новину. ${ }^{3}$ У том смислу, Драгана Вукићевић (2005)

2 „Ниједан српски књижевник 19. вијека није био тако неправедно потиснут у дуготрајни заборав, а да је имао тако потпуно, поетички и жанровски разноврсно и богато приповједачко дјело, мада је живио сасвим кратко и није стигао да искаже истинске умјетничке потенцијале, као што је био случај са Илијом Вукићевићем." (Максимовић 2013: 164)

${ }^{3}$ Драгана Вукићевић у тексту „Српска реалистичка приповетка и фолклорна традиција" (2005: 594-595) истиче да се феномен фолклорног у приповедној прози српских реалистичких писаца манифестовао у три вида. Док први вид представља сакупљачки рад реалистичких аутора, други облик подразумева поступке којима су поједини приповедачи „покушали да мимикрирају своје ауторске интервенције и дело представе као фолклорно па је други начин манифестације фолклорног препознат у мистификацијама. 
запажа да различите терминолошке синтагме под којима се уметничка бајка код Срба појављивала - стилизована (народна) бајка, уметничка бајка са јасно препознатљивим елементима народне бајке, литераризована народна бајка итд. - указују на прелазни статус уметничке бајке, односно на процесе којима су жанрови усмене књижевности прелазили у дискурс писане литературе и постајали самостални жанровски облици. У тексту „Српска реалистичка приповетка и бајка" Драгана Вукићевић (2005: 373374) анализира моделе транспоновања народних жанрова у контексту штампане књижевности, при чему истиче да се процес трансформације одвијао према владајућем поетичком логосу. Тако, 30-их и 40-их година 19. века у српској штампаној књижевности развија се тзв. „хипертрофирана бајка". Овај бајковни тип претрпео је снажан утицај просветитељске традиције, те је стваран са изрази-

Трећи облик се препознавао у стваралачким интерференцијама, синтезама (не више симбиозама) фолклорног и индивидуалног/ауторског стила. У оваквим текстовима, већ променом контекста, потајно или делимично цитиран фолклорни предложак престајао је да значи оно што је значио у свом аутентично фолклорном облику. Проблем граница је притом усложњен gвосиируком кониексииуализацијом фолклорноі йреgлошка - с једне стране, он чува границе сопственог жанра и његову морфолошку самосталност, а са друге стране почиње и завршава се тамо где почиње и завршава се реалистичка приповетка. (...) Уместо директних цитата и парафраза, реалистички приповедачи су чешће прибегавали семанишичкој йрансйозииији фолклорног предлошка. Реч је о алузијама, асоцијацијама на свет фолклорног, најчешће на одређене јунаке. Алузијама и асоцијацијама реалистички приповедачи су, по правилу, утврђивали традиционално знање о свету док су га пародичним, ироничним и хумористичким транспозицијама релативизовали. Цитатне релације су притом варирале до укључивања туђег у властити текст (стилизације, пародије, травестије), делимичним пресеком потпуних или делимичних цитата конкретног фолклорног записа." 
том функцијом наравоученија. Имплементацијом фантастике предања „хипертрофирана бајка” задовољавала је помодни укус публике склоне причама страве и ужаса какве је форсирала западноевропска традиција готског романа. Бајка из 60-их и 70-их година у контексту нове реалистичке књижевности добила је другачију функцију.

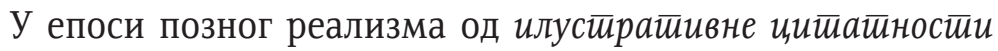

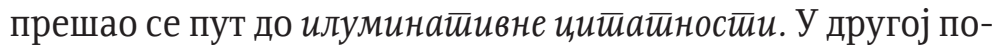
ловини века дошло је до разарања и дестабилизације бајковног жанра чиме се изражавао смисао који се језиком реалистичке прозе није могао изразити на прави начин: „Реалисти су прибегли другостепеном поступку дизентеграције жанра - бајка се „сказом” са првостепеног нивоа диегезе померала ка другостепеном нивоу диегезе чиме се отворио простор за хумористичне, ироничне и пародичне интервенције наратора". (Вукићевић 2005: 374) Жанровско вишегласје у фантастичном дискурсу касног реализма, кретао се у правцу доминантних поетичких координата. Оксиморонски спој узвишене бајковне фантастике и реалистичког проседеа (шаљива и сатирично-алегорична прича), усмеравао се у српској уметничкој бајци у правцу реалистичнијег поглада на свет.

Критичка интертекстуалност један је од централних проблема Вукићевићевог фантастичног дискурса. Бајковни израз овог приповедача настаје пародичном имплементацијом хетерогених жанрова фолклорне традиције у нови контекст писане, реалистичке литературе. Вукићевићева бајка представља полифону интертекстуалну мрежу коју карактерише снажан асимилациони потенцијал и широка отвореност према опречним семантичко-синтагматским формама - према фолклорној бајци али и према новели и шаљивој причи. Постављањем двоакценатских облика у исту раван, Вукићевић са примарне мимезе прелази на другостепену мимезуфолклорног бајковног предлошка, 
чиме остварује компетенције за рецепцију хумористичких, пародичних и других реалистичних елемената. Поступцима дестабилизације и трансформације усмене бајке ка реалистичнијем доживљају стварности, Вукићевић се у потпуности уклапа у књижевне тенденције уметничке бајке с краја реалистичке епохе.

Као илустративни пример процеса који су се одвијали у уметничкој бајци позног реализма, могу се узети тексто-

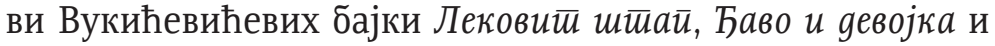
Сйрашан сан. ${ }^{4}$ Применом интертекстуалног приступа на примеру одабраних текстова, може се пратити поступак имплементације фолклорних жанрова, њихово укрштање и прилагођавање контексту реалистичког писма. Поступцима интертекстуалног уношења примарног текста у секундарни текст, као и облицима постојања унесеног текста у датом дискурсу, бавио се Зоран Константиновић у

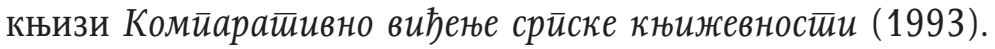
Константиновићева теоријска поставка интертекстуал-

4 Горан Максимовић (2013: 164-167) Илију Вукићевића оцењује као мајстора приповедања, при чему, његову бајку види као претечу модерне прозе у Срба. Максимовић Вукићевићево приповедање разврстава у три тематско-мотивске целине, при чему фантастичну прозу види као посеблу целину. Према Максимовићу прву целину чине реалистичко-миметичке приповетке са тематиком из сеоског (Комшије, Све сам знаш, Каg није суђено, Је ли

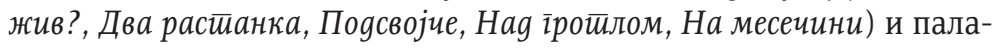
начког живота (Јемаи, Прво унуче, Поg баїреном, Свој іррех, У новој $\kappa y \hbar u)$. Другу целину чине натуралистичко-психолошке приповетке са тематиком из живота на српско-арнаутској граници на југу Србије (Граничари, Неколико слика из животиа јеgної јунака, Поg сунием, Шкрбо и Фејзула, Мала йоірешка, На сиражи). Трећу целину чине гротескно-фантастичне приповетке (Прича о селу Врачима

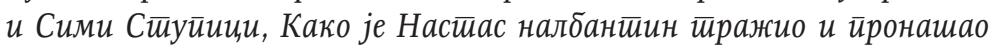

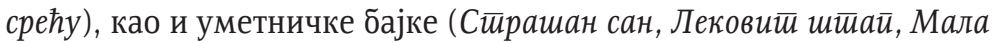

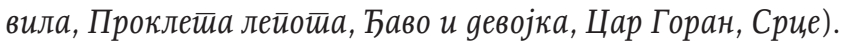


ног односа, као и класификација облика постојања унесеног текста, могу послужити као полазиште за анализу веза између Вукићевићеве уметничке бајке и фолклорних жанрова. У том смислу, осврнућемо се на оне ставове Константиновићевог интертекстуалног приступа који су кључни за ову прилику.

Пре свега, појам цитата Зоран Константиновић (1993: 144-168) дефинише много шире у односу на традиционално поимање овог појма. Према овом аутору цитат се у књижевном делу може јавити као посредно или непосредно навођење туђих исказа, мотива и тема, форми и уметничких поступака, при чему се као најсуптилнији и најсложенији вид цитата узима преузимање метафизичких квалитета. У новом окружењу, унети исказ може се јавити у неколико форми, као йоgражавање извора, реминиси,ени,ја или пак алузија. Форма йодражавања (имийаuије) извора, настаје приликом литераризације неке познате историјске личности. Чест је случај да књижевници у свој дискурс уносе неку познату личност и приписују јој фиктивне исказе које су оне тобож казале и притом те исказе стављају под знаке навода. У овом случају писци прибегавају поступку имитације стила и израза одређене личности, а не и истинитог навођења њеног исказа. Непосредно интерполирани исказ, у новом литерарном контексту може се јавити и у форми реминисценције. Уколико у тексту наиђемо на мотив невесте који је интерпретиран у библијском, химничном стилу, и то без навода, изазваће сећање на библијски лик из чувене Пјесме наg иесмама. Под алузијом Константиновић подразумева ситуацију у којој се извор само овлаш назначава и при том се не помиње његово значење (нпр. бројни микенске и тројанске алузије у песништву Црњанског).

Цитат из туђег дела може се јавити и у виду позајмљеног мотива или теме. Под цитираним мотивом подра- 
зумева се његова литераризација у којој долази до неке одређене варијације изворног облика. Обрада мотива и тема често је повезана са улогом ликова у неком књижевном делу. Зоран Константиновић истиче неколико обли-

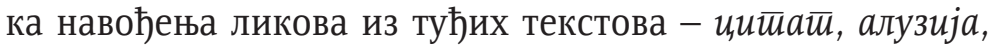

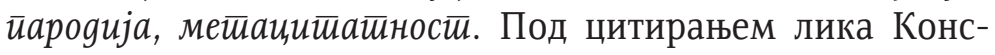
тантиновић подразумева помињање лика из неког другог текста, његово подражавање као и преузимање у целости. Осим непосредног цитирања, ликови се могу јавити и у форми алузије, као мање или више препознатљиви. Посебане видове преузимања ликова представљају негативно цитирање или пародија, као и метацитатност под којом Константиновић подразумева интерполацију стварне личности у литерарни контекст.

Као најсложенији вид цитатности у књижевном делу, Константиновић наводи преузимање метафизичког слоја дела. Приликом интертексуалног истраживања, могли бисмо се питати који нас метафизички квалитети у датом књижевном делу подсећају на неко друго дело. То може бити квалитет трагичности, комичности, мистичности, недостижности, љупкости и сл.

\section{Лековити штап}

У процесу интертексуалних односа, бајка Лековити и

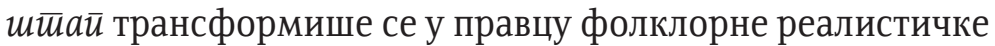
прозе - новеле и шаљиве приче. Довођењем у оксиморонску везу узвишеног света бајковне фантастике и „приземне", хумористичко-пародичне тенденције реалистичког дискурса, дошло је до потпуног инверзирања бајковног жанра, који се од традиционалне окренуо ка гротескнофантастичној форми. И на формалном и на садржинском плану елементарни бинарни систем у Вукићевићевој бај- 
ци постаје полазиште за пародијску инверзију опозитних парова. Механизми оваквог изокретања активирају се кроз следећи систем: узвишено/тривијално, дозвољено/ недозвољено, фантастично/хумористично, лепо/ружно, високо/ниско. ${ }^{5}$ Насупрот узвишеном свету бајковне фантастике Вукићевић литераризује тривијални, ниски свет новелистичке карикатуре, пародије и комике. Овакав парадоксални спој бинарних елемената најлуцидније се запажа кроз поступак пародичног цитирања кључних структурних етапа фолклорне бајке које је поставио Владимир Проп у чувеној Морфолоїији бајке (1982).

Већ на самом почетку, Вукићевић типизираном наративном формулом „била једном једна жена...” активира добро познату семантичко-синтагматску осу фолклорне бајке. Експликацију одређеног хоризонта очекивања Вукићевић убрзо дезинтегрише комично-пародичном интерпретацијом идеализованих бајковних ликова. Пародија Вукићевићевих јунака додатно је интензивирана снажним хиперболама:

Била, тако, једном једна жена и звала се Осица, али ни сама зоља није могла љуће убости жаоком, као ова Осица језиком. Свугде је њена била прва и последња, и никоме се она није дала да се претече, а ниједан поп није могао речи пред њом: 'Амин!' а да она не дода: 'Амин, попе!' Па јој још Бог даде чуднога човека за мужа, јер њен бан

5 „Хумор се (...) појављује као комплексан феномен који најлакше подрива остале наративне норме. Типови комике се активирају и на тематском ниову, те је оксиморонска инверзија вишеструка. Опозиције узвишено/тривијално, лепо/ружно, високо/ниско испољавају доминацију негативног члана у пародијском комплексу. У оваквим жанровско-тематским комбинацијама несклад садржине и форме служи или пренаглашавању (забрањених) тема или потенцира карикатуралност актера у тривијалном догађају." (Самарџија 2004: 104) 
није умео свезати две речи заједно, а да се не почеше по глави и да другој не одгризе крај. Тај се њен човек звао Маринко, и био је за педаљ нижи од Осе, нешто поткус у пасу и омало накрив на леву страну. А од памети своје ни за лека коме да је да! Ако узме кашику једном руком, морао је другом отворити уста, да би знао где ће је унети, и после је с тешком муком извлачио испод зуба, а двема је тако одгризао лопаре и једном је појео пола зделице заједно са кајмаком. (Вукићевић 1929: 285)

Оваква пародично-хиперболична слика нарочито је дошла до изражаја у лику мужа Маринка, где бизарност преувеличавања долази до границе апсурдног

Маринко скиде фес и поче прву реч, али већ на другој страни му паде језик на зубе и не знаде рећи шта је хтео. (...) Ако узме кашику једном руком, морао је другом отворити уста, да би знао где ће је унети, и после је с тешком муком извлачио испод зуба. (Вукићевић 1929: 285)

У жанровско-тематској комбинацији несклад садржине (бајковне фантастике) и форме (новелистичког стилског арсенала) служи карикатуралној карактеризацији актера у бизарним догађајима. Наглашена ругалачка

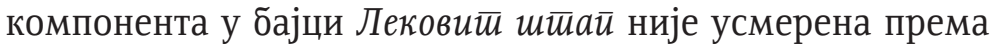
жанру бајке, него је уперена против понашања и односа мужа и жене. Пародијска дистанца у бајци је захватила опонентно понашање актера који одступају од канона

${ }^{6}$ „Управо фигуративност песничког језика допуштала је да се пародијска перспектива појача ослањањем на хиперболу, метафору, паралелизам или оксиморон. И саме фигуре у новом контексту добиле су другачију улогу, мењајући сопствено значење и смисао целине (варијанте). Хипербола је приближена карикатури, метафора апсурду, а паралелизам и оксиморон огољени су до бесмислице." (Самарџија 2004: 102) 
патријархалног контекста. Основни уметнички циљ интертекстуалног учитавања новелистичког жанра у бајковни контекст, у овом случају представља пародијско преиспитивање и критиковање инверзираног односа мушког и женског принципа.

Целокупан догађајни ток у бајци обавијен је гротескном и карикатуралном уметничком сликом. Овакав стилски ефекат постигнут је активирањем технике изокренуте слике света. Артифицијелна, неприродна и хиперболисана слика мотивисана је ротацијом родних улога, те извештачена и усиљена концепција супериорне жене и глупог мужа на карикатуралан начин представља сву „неприродност" женске доминације. Концепцијом света у коме су инверзиране вредности (жена је физички крупнија, супериорнија, храбрија), Вукићевић је на карикатуралан начин изразио „поремећени”, „ишчашени” и „изокренути” свет у коме жена представља водећи принцип.

Након пародичног цитирања бајковног јунака, и делокруг фантастичног бића које упућује Маринка дариваоцу чаробног средства/савета, добио је комичну реинтерпретацију. На то указује нонсенсна слика коса који говори, пуши лулу и спрда се са Маринком. Такође, дата је и саркастична литераризација бајковне функције дариваоца чаробног средства, као и самог чаробног савета. Вукићевић кроз поступак пародичне алузије активира литерарни топос мудрог старца који живи у шуми и поседује фантастичне моћи. У основи лика дариваоца чаробног средства запажамо инверзирану фигуру старословенског стиари, (gega) који представља инкарнацију душе претка. Према многобожачком веровању дух претка који је замишљан као старац, поседовао је способност метаморфозе и најчешће се претварао у змију. Старцу је приписивана функција патрона, он је штитио кућу, њену децу и имовину. (Кулишић и др. 1970: 275)У Вукићевићевој бајци дарива- 
лац чаробног средства поседује атрибуте који га повезују са старословенским веровањем у старца као инкарнацију душе претка. Са старословенским веровањем у духа претка Вукићевићевог јунака повезују пропратни атрибути, шубара од курјачине и штап са змијином главом. Вук у фолклорној традицији представља хтонско биће и инкарнацију душе претка. Курјачином се на дан Божића код Срба огрће положајник (положеник) који симболизује претка дома. Исто тако, на фигуру претка заштитника асоцира и старчев штап са змијином главом. Према фолклорном веровању и змија представља хтонско биће, најчешћи вид теоморфне метаморфозе душе претка. Штап је такође стални атрибут светога Саве и светога Јована. У фолклорној литератури штап поседује изразиту симболичку моћ, њиме се заустављају несреће, гоне се ђаволи и чине разна чуда. (Кулишић и др. 1970: 310-311) У фантастичном свету бајке старчев штап се може посматрати и као национална интерпретација универзалног мотива чаробног штапића из светске литературе. На старословенску фигуру старца, Вукићевићевог јунака везује и функција заштите коју треба да пружи Маринку и његовом дому - спас од зле жене. Интертекстуално позивање на атрибуте и функцију духа претка, прожето је у Вукићевићевој бајци снажном иронијско-саркастичном цртом. У овом случају жена добија симболички статус злог духа који је пореметио благостање дома, због чега је основна мисија старца постала спасење кућног мира. За фигуру стараца Вукићевић везује и општи мотив фолклорне литературе мудроносних (у епици староставних) књига у којима је похрањено целокупно благо мудрости, па и лек за злу жену: „...диже се онда стари донесе однекуда књигу, дебелу као балван, са корицама од воловске коже и сва гвозденим карикама поткована ..." (Вукићевић 1929: 288) 
Карикатурална фигура бајковне функције дариваоца чаробног средства узрокована је изразитом ироничном и мизогеном цртом бајке. То се најуочљивије запажа у комичној ситуацији у којој од разгоропађене жене око чаробног казана беже и преплашени старац-предак и збуњени Маринко:

Старцу заклецаше ноге, те му брада поче мести по земљи, а рукама подухвати бутине, као да тражи место где ће сести. Маринко утече иза казана, згури се сав с друге стране и поче да извирује преко поруба. (Вукићевић 1929: 291)

Такође, и функција бајковног савета о батини као „леку" за сваку људску „болест”, па и за злу жену, добија изразити иронично-сатирични тон. У том контексту се и „ррећни" бајковни крај претворио, додуше мимо ауторове намере, у антиутопијску и дехуманизовану слику света. Савет у Вукићевићевој бајци представља инверзирану варијанту савета праве бајке, који треба да донесе уравнотежену и хармоничну слику идеализованог света. Бајци

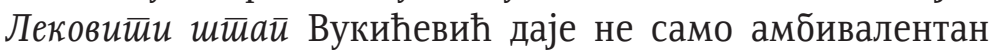
почетак, него и проблематичан крај. Само на први поглед синтагматична оса није одступила од жанровских норми бајке. Однос међу јунацима (насилно решавање проблема) пародијска је негација дуговечне брачне слоге из финалних формула бајки. У оваквом контексту бајковни епилог: „Отада су живели Оса и Маринко као голубови” добија одлике фингираног и иронизираног начина обраде идиличног краја бајке. 
Ђаво и девојка

Бајку Ђаво и gевојка карактерише сложени жанровски синкретизам настао интертекстуалним преплитањем етиолошке фантастике библијске литературе, фолклорне бајке, клетве и загонетке-питалице. У процесу интертекстуалних односа, оквирни догађајни ток трансформише се у правцу религиозне етиолошке параболе која тумачи настанак порочне стране женског бића. Процес учитавања библијске литературе може се пратити кроз поступак интертекстуалног цитирања мотива. Екстрадијегетички приповедни ток конципиран је на фантастичном сукобу између ђавола и светог Аранђела и тематизује интернационални мотив о ђаволу који куша божанску душу. Попут чувене Књиіе о Јову у којој сотона тек уз божју дозволу и сагласност може да куша праведну Јовову душу, и у Вукићевићевој интерпретацији ђаво добија статус подређеног духа. Сама констатација да о коначној судбини девојчине душе доноси одлуку свети Аранђел, луцидно указује на ђавола као на субординирано биће.

С друге стране, у Вукићевићевом тексту библијски мотив о ђаволу кушатељу добија нешто другачији литерарни вид у односу на старозаветну верзију. Разлика између старозаветног архетипа и Вукићевићеве интерпретације мотивисана је продором елемената из реалног живота и националног културног контекста. Најпре, сукоб око људске душе код Вукићевића се не водиизмеђу бога и ђавола, него између светог Аранђела и ђавола. Тако је општу хришћанску фигуру бога у овом случају заменила национална појава светог Аранђела. Национално и реалистичко у лик светог Аранђела продире заједно са фолклорном формулом клетве којом проклиње злу душу и претвара је у огледало. Кроз лик свеца продире паганско веровање у окултну, магијску функцију речи, у мистичну и необја- 
шњиву моћ човека да путем посебних лексичких формула комуницира са вишим сферама и хтонским бићима.

За разлику од познатог старозаветног мотива о пакту склопљеном између бога и ђавола кушатеља, Вукићевић обрађује мотив ђавоље подвале свецу. Према Вукићевићевом тумачењу, грешна страна женског бића настала је као последица ђавоље преваре: лукави демон успева светом Аранђелу да подметне злу људску душу, док за себе приграбљује добру. Разобличивши превару, светац проклиње злу душу и претвара је у мистично огледало, које по прастаром веровању одржава везу са оностраним светом и поседује магијску моћ. Укрштањем добре и зле душе, односно, њихове инкарнације у виду племените девојке и уклетог огледала, настаје амбивалентна природа женског бића. Посматран у оваквом контексту, мотив ђавола који наговара жену на зло има свој прототип у библијској легенди о Еви и змији као инкарнацији ђавола. Кроз поступак интертекстуалне реминисценције, Вукићевић учитава у бајковни текст библијски архетип о жени која наседа на превару и спознаје први грех. Како је лукава змија-ђаво преварила Еву да проба јабуку са дрвета сазнања и тиме је из утопијског хронотопа раја нахушкала у стање греха и порока, тако је ђаво у Вукићевићевој бајци инкарниран у добродушну старицу поклонио девојци огледало и сурвао је у царство греха, привида и слабости. У том контексту огледало у Вукићевићевој бајци добија метафорични статус старозаветне јабуке, инкарнације људског греха.

у спољашњем приповедном рукавцу, присуство хришћанског слоја препознајемо и кроз интертекстуално цитирање метафизичких квалитета библијског канона. Продор метафизичког слоја хришћанске литературе, сагледавамо у религиозно-моралистичким коментарима. У експлицитној форми Вукићевић износи моралистичкоетичке семантизације о несавршеној и биполарној приро- 
ди човековог бића уопште: „Нема добре душе на свету, ни девојке која ће свему одолети." (Вукићевић 1929: 314) Цитирање дубинских квалитета хришћанског канона, може се запазити у религиозним контемплацијама о таштини и пропадљивости телесног, које иронизирају интернационални мотив прелепе и нарцисоидне жене. У том смислу треба читати ауторову моралистичко-ироничну дистанцу у опису девојчине смрти:

И тако до суђеног дана, а тога дана леже девојка, мучна и немоћна, и само чека крај. Окитила се ђерданима, али јој жута кожа, те се злато не види од ње. Крај ње је огледало, али јој слаба рука, па не може да га подигне. (Вукићевић 1929: 316)

У складу са хришћанском (месијанском) логистиком, и у Вукићевићевој бајци божански принцип не напушта заблуделу душу. Иако девојка пада у грех (постаје охола, нетрпељива, престаје да поштује старије и да иде у у цркву) не бива кажњена. У финалном драмском сукобу између светог Аранђела и ђавола девојка бива спашена:

„И Свети Аранђел спусти руку на девојчина уста и извади из њих онај цвет бео, чист и нетакнут.

- А твоје је - рече после врагу, - ето то грешно тело, које си ти преварио! (Вукићевић 1929: 317)

Мотив спасења божанске душе на библијском фону покреће интригантна питања која финале бајке остављају отвореним за бројна тумачења. Када у грешном телу душа остаје чиста? Да ли тек ослабађањем од тела почиње прави и чисти живот људске душе? Слично Гетеовом Фаусту, и Вукићевићева јунакиња пролази кроз бројна искушења у борби са ђаволом, окуси грех али се не испрља злом, осети телесно али не заборави духовно, спозна ђавола али не напусти Бога. 
На фону метадијегетичког наратива Вукићевић активира богати свет фолклорне фантастике. На фону унутрашњег наратива, осећа се утицај фолклорног предања Жена и ђаво, као и фолклорних бајки Зла жена и Баво и њеі̄ов шеїрй. Сличност између етиолошко-демонолошког предања Жена и ђаво и Вукићевићеве бајке Баво и gевојка, најпре се запажа у самој насловној формули, а потом и у фантастичном тумачењу постанка тамне стране женске природе. Разлика је у изразитој мизогеној, сатиричној црти која прожима фолклорно предање, а која није карактеристична за Вукићевићеву бајку. Према предању жена и ђаво се потукли у воденици:

Жена била сналажљивија па истуче ђавола те овај јурне 'да је удави'. Анђео хтеде да погубии ђавола мачем, 'те у том одсече жени и ђаволу главу једним махом'. Виде да је погрешио па оде те то каже богу. Овај му нареди да жени опет стави главу на тело, па ће она оживети. Анђео погреши и стави ђавољу главу на њено тело; отуда жене не скидају капу у цркви кад се богу моле. (Латковић 1991: 105)

Веза са фолклорном бајком пре свега се запажа кроз поступак цитирања уметничке форме усмене бајке. Посматрано из перспективе Пропове Морфолоіије бајке, можемо успоставити следећу композициону схему Вукићевићеве бајке:

(i) Почетно стање (слика хармоничног и уравнотеженог света);

(X) Нарушавање почетног стања (ђаво на превару подмеће светом Аранђелу злу, а за себе узима добру људску душу);

(L) Борба са штеточином (сукоб ђавола и девојке утемељен на прастаром, интернационалном мотиву метаморфозе душе); 
(V) Победа над непријатељем и повратак почетне, уравнотежене слике света (бајковни топос идиличног краја - девојчина душа се на крају враћа у божанско окриље).

У Вукићевићевој бајци делокруг главног јунака припао је доброј души, делокрог штеточине ђаволу, док делокруг помоћника припада светом Аранђелу. Као и у фолклорној бајци, и код Вукићевића долази до изненадног напада штеточине која нарушава почетну слику уравнотеженог света. Сама фигура штеточине у Вукићевићевој бајци добија основне фолклорне атрибуте демона: везан је за хтонски простор воденице, склон је преварама и поседује способност трансформације. Целокупни демонолошки свет Вукићевићеве бајке литераризован је у складу са националним фолклорним веровањем. Уочљива је фолклорна појава баука, хтонског бића које открива ђаволу девојчине слабости и открива му уклето огледало 7 . У Вукићевићевој бајци баук је настањен у простору који прати фолклорна атрибуција оностраног простора:

Најпосле, једне ноћи западне у неку пусту шуму и виде једну напуштену воденицу, са пребијеним витлом, којој само ветар отклапа и заклапа врата. Ту чу где се ћук са врбе и баук испод воденице разговарају. Ђаво се претвори у ветар и поче да пролеће између њих. (Вукићевић 1929: 313)

Фантастични сукоб између девојке и ђавола одговара функцији тешких задатака и препреки које протагониста мора да изврши у традиционалној бајци како би ишчаше-

7 „Баук се у народу замишља као страшило у животињском облику, које својом појавом улива страх. Баук се дању крије по кутовима запустелих кућа, рупама и мрачним местима, отуда вреба жртву да је уграби, однесе, удави и прождере." (Кулишић, Петровић, Пантелић 1970: 20) 
ну и дисхармоничну слику света вратио у првобитини баланс. Интерпретација сукоба ђавола и девојке показује одређене семантичко-структурне сличности са фолклорном бајком Ђаво и юет̄ов шеїрй. Структурна оса и фолклорне и Вукићевићеве варијанте утемељена је на прастаром, интернационалном мотиву метаморфозе душе. У Вукићевићевој бајци борба ђавола и девојке се развија кроз низ епизода у којима протагонисти пролазе кроз теоморфне, зооморфне и антропоморфне видове, надметајући се лукавством и довитљивошћу. Трансформисан у лик добродушне старице која девојци поклања уклето огледало, ђаво успева да је нахушка у своје царство греха и порока. Вукићевић у бајци активира универзални и добро познати литерарни топос злог духа инкарнираног у слабашну и добродушну старицу која чаробним предметом наноси зло бајковној јунакињи. Најпознатија варијанта јесте Гримова литерарна обрада овог мотива у бајци Снежана и се-

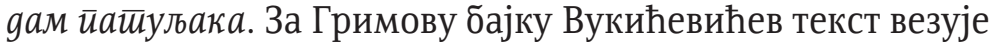
и мотив чаробног огледала. У оба бајковна текста главни подстрекивач кобног заплета јесте чаробно огледало које поспешује сујетне и нарцисоидне женске пориве (код Грима је то зла мећеха, а код Вукићевића добра девојка). Док је у Гримовој варијанти чаробна моћ огледала везана за фантастичне атрибуте маћехе (она је вештица), у Вукићевићевој бајци универзални мотив чудесног огледала добио је националну реинтерпретацију. Вукићевићево тумачење о постанку чаробног огледала као инкарнације зле душе, у бајковном дискурсу добија одлике етиолошко-демонолошког предања у које је инкорпорирана форма фолклорне клетве: „Немала никад лица, немала никад мира, немала никад срца, а у теби се цео свет видео." (Вукићевић 1929: 309)

Само финале уметничке бајке одговара семантичкосинтагматској оси прототипа фолклорне бајке, те доноси 
утопијско разрешење нарушене хармоније и равнотеже с почетка текста. Божанска душа која пролази дуг пут искушења враћа се божанском царству, и тиме попут бајковног протагонисте успева да поврати доминацију позитивног принципа.

\section{Страшан сан}

Инверзирање семантичке и структурне атрибуције канонске бајке,у бајци Сйрашан сан мотивисано је прстенастим композиционим решењем. Цитирањем уметничких поступака карактеристичних за реалистички поетички контекст, екстрадијегетички наратив бајке се трансформише у правцу писане, реалистичке литературе. Наиме, техником сна Вукићевић на реалистичики начин мотиивище свет фантастике и тиме подрива повлашћени положај фантастичног у бајци. Постављањем реалистичке мотивације у основу текста, Вукићевић је инверзирао основне поставке фантастичног света традиционалне бајке која истинитост и самодовољност фантастичног никада не нарушава. Приповедач се, заправо, поиграва мотивационом логистиком бајке у којој чудесно поседује недвосмислен статус вероватног и могућег:

Стављање бајке у конкретни друштвеноисторијски контекст (реалистички хронотоп) грубо је структурално одступање од конвенције бајке, од времена које по Лихачову не 'постоји ни пре почетка ни после завршетка приче'. Уместо да бајка почиње 'из небића, из одсуства времена и збивања', реалистички приповедачи су, тематизујући нови хронотоп и смештајући је у један шири контекст нарушили њену жанровску самодовољност. (Вукићевић 2005: 378) 
Унутрашњи наративни прстен обухватио је фантастични свет сневаног. На метадијегетичком нивоу, Вукићевић путем пародичног интертекста (дез)активира четири типа фантастичног - бајковну, ониричку, библијску и епску фантастику. Процес пародичног инверзирања фантастичног света у основи је мотивисан поступком подражавања фолклорног јунака новеле, Ћосе. Имплементацијом новелистичког лика отворена је могућност за оксиморонско укрштање бајковног и новелистичког жанра, чиме је активирана хумористичко-пародична реинтерпретација бајковне фантастике. Пародија и инверзирање бајковног јунака постигнута је заменом идеализованог хероја неотесаним, комичним и приземним јунаком новеле. Кроз инфантилну и припросту свест јунака, сакралност и узвишеност библијског есхатолошког учења о постнатуралном животу, преноси се на ниво комичне и гротескне диегезе бајковног света. У ониричко ткиво трансформише се подсвесни садржај главног јунака, чиме се ствара погодан просторза продор реалија свакодневног живота. У таквим околностима, гротескна слика оностраног света постигнута је продором сировог и приземног метеријала из реалног живота у префињени и сакрални свет хришћанске литературе. Будући да ради као шегрт у дућану, Ћоса „мерење” грехова и доброчинстава замишља кроз слику младог и лепо одевеног светог Петра који на теразијама мери добро и зло. Кроз гротескну слику у којој је свети Петар описан као млади и имућни дућанџија, а преплашени Ћоса као трговац који са светим Петром и ђаволима „преговара” о „куповини” рајског живота, дата је комична инверзија и бајковне и религиозне фантастике. Ефекат комичног интензивира се успостављањем фамилијарног односа између светог Петра и Ћосе. Светац-патрон обећава „своме” Ћоси да ће „већ гледати” ако што може да учини да га „пребаце” у рај: 
Кад рече: Петар, скочи Ћоса и викну кроз плач: - Не дај ме, Свети Петре, не дај ме, ти си моја слава!

- Добро, добро - рече Свети Петар, - већ гледаћемо, ако се може како, само прво да се измериш на оним теразијама, да видимо јеси ли грешан или ниси. (Вукићевић 1929: 277)

Обликовање лика подвалџије кога прате несташлуци, ситне крађе и преваре, мотивисано је поступком цитирања фолклорних атрибута Ћосиног лика:

Због неприродних особина и необичног изгледа, ћосавим људима се приписивала тајанствена моћ. Осим тога, ћоси је урођено да учини превару, ма и немао од ње никакве користи. Зато га људи избегавају, јер сматрају да га је Бог апосторфирао одузимањем бркова. (Кулишић и др. 1970: 289)

И у Вукићевићевој бајци Ћоса је задржао епитет подвалџије који је склон преварама и лукавствима. Скромни живот јунака, банални грехови и несташлуци, као и борба за ситним користима (украдено огледало или каиш, неплаћена чаша вина, обрисан рачун у кафани и сл.), уносе енергичност и свежину у малокрвну и сувопарну реторику религиозне литературе. Интерполирањем обичног света дућанџија, шегрта и механџија, свет фантастике се „спушта" ка сировом али животворном хронотопу, чиме се у бајковни жанр уноси реалистична тенденција.

Заједно са Ћосиним ликом у софистицирани простор бајковне фантастике веома успешно продире и колоквијални говор. Оксиморонски спој узвишене бајковне лексике и свакодневног говора литераризовао је комично-пародичан стилски ефекат. Цитирањем технике сказа, апстрактни и високопарни језик бајковне фантастике „пада” на ниво другостепене мимезе стила усмене гатке: 
Ја сам из Пажева, с оне стране потока, где је Чутурова воденица, и зовем се по крштењу Симо, ал' ме да прозвали, да простиш, Ћоса. (Вукићевић 1929: 276)

Снажнији ефекат комичног постиже се стављањем колоквијалног говора „у уста” и самом светом Петру:

Не мо'ш, синко, одмах овамо, но ми се кажи ко си и откуда си, само прво скини капу, јер се овде не стоји под капом: ово је свето место. (Вукићевић 1929: 275)

Добро, добро, синко, а што си у прошли 'торник узео грош оном слепцу из феса, па си после утекао по ћуприју и остао онде толико? (Вукићевић 1929: 276)

Комични заплет - Ћосино испаштање пред Страшним судом, кулминативну тачку достиже у тренутку укрштања уметничке бајке и фолклорне шаљиве приче засноване на мотиву зле жене од које дрхти сав пакао и рај. За разлику од библијске литературе у којој есхатолошка догма увек има неку вишу, моралистичку функцију, код Вукићевића служи искључиво за постизање ефекта комичног. У таквом контексту, као комични услов за јунаково искупљење на оностраном свету, Вукићевић поставља опроштај чангризаве и свадљиве баба-Журне од које и фантастична бића безглаво беже:

Кад чу (бабу) онај матори враг, дохвати се брзо руком за реп и скочи у онај котао, а остали улетеше у неке рупе по странама, а оног најмањег стаде писка и, кад баба стиже на отвор, он улете у ону ватру под котлом и зари се сав у жар. (...)

Свети Петар испусти кључ из руке, па се брзо сакри иза Светог Аранђела. А Аранђел остави теразије и дограби оберучке за мач, и кад уто упаде баба, он поче махати око себе на све стране! (Вукићевић 1929: 283) 
У оваквој гротескној слици бајковног света, изостају сви препознатљиви формално-садржински елементи овог жанра. Нестало је ваљаног јунака, племенитог циља, уздрмане слике стварности и борбе која тријумфује у знаку победе доброга. У таквој уметничкој атмосфери доминира комична игра која вртоглаво и живахно изокреће свет, при чему бурлеска, хумор и забава постају доминантни квалитети.

Постављањем лика-фокализатора, Вукићевић разара и неке од базичних наратолошких одлика бајковног поетичког писма. Насупрот бајковном наративу који је увек нулто фокализован, Вукићевић уводи за бајку сасвим нетипичну приповедну стратегију - унутрашњу фокализацију. Концепцијом фокализованог приповедања долази до негацијебајковне категорије објективног и поузданог приповедача. Субјективизацијом и психологизацијом бајковног ткива свет фантастике употребљен је у психолошкој (компензаторској) функцијив:

Наже се Ћоса над обалу и погледа у воду и умало'се не преврну стрмоглав од чуда и радости. Погледа још једном и виде лепо себи под носом дуге црне брке, па га чисто голицају око усана. Тада ти се он јуначки раскорачи, испе прса и ухвати се десном руком за десни брк (болд М. С.) и - нешто закокота и тресну крилима, стаде дрека кокошака, а Ћоса се из сна трже. (Вукићевић 1929: 284)

${ }^{8}$ У својој књизи Евройска нароgна бајка Макс Лити наводи јеg-

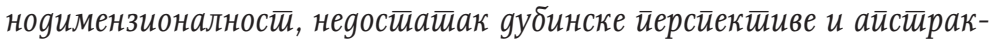
$\bar{u} н и$ стиил као неке од круцијалних особина народних бајки. Недостатак gубинске иеррсиекиииве према Литију (1994: 16) подразумева бестелесност бајкових ликова, они су „без унутрашњег живота, без окружења; недостаје им веза са прошлошћу и са будућношћу, са временом уопште." 
Комични тон психолошке (компензаторске) фантастике интензивира пародично подражавање химничког израза епске фантастике. Комично-пародични ефекат постиже се изразитом опозитном дистанцом између света психолошке фантастике и реалног света. На поступку контрастирања Вукићевић утемељује низ комичних слика. Фигури ћосавог, смешног и плашљивог јунака који припада стварном свету, на комичан начин опонира епску, космату и неустрашиву појаву хероја на коњу. Ефекат комичног постиже се пародичним цитирањем формула из реторичко-стилистичког арсенала епске фантастике. Трансмисијом готових стилистичког „опека” („седло од црне чоје”, „све шарено жутим мерџанима”, „фркће кроз ноздрве”, „висе златне ките и лупкају по трави”), у потпуно супротни контекст долази до комичног инверзирања простора у који улази:

Кад погледа после више себе, а он лежи на зеленој ливади, а до њега зелен коњ са зеленом гривом до земље, закопава предњом ногом у траву и фркће кроз ноздрве. На њему седло од црне чоје и све шарено жутим мерџанима, а са четири му краја висе златне ките и лупкају по трави.Чим се Ћоса диже, а коњ клече на предње ноге и рече: 'Јаши ме, ако ти је воља!' (Вукићевић 1929: 18)

Драгана Вукићевић запажа (2005) да Ћосин лик, иако преломљен кроз епски, религијски и бајковни свет, ипак не припада ниједном од тих светова. Вукићевићев јунак, заправо, представља пародичну, инверзирану варијанту и епског и религијског и бајковног јунака. Голобрад, плашљив и слабашан, Ћоса представља комичну интерпретацију епског хероја. Спреман на ситне несташлуке и компромисе за лагоднији живот Ћоса представља и инверзију религијског и бајковног јунака. Вукићевићев јунак једино 
припада свету из којег потиче. Он се уклапа у сирови, реалистични, комично-пародични свет фолклорне новеле.

Све три уметничке бајке, Баво и gевојка, Лековити и

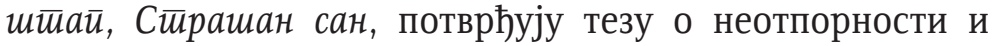
трансформацији фолклорног бајковног прототипа који се с краја 19. века нашао унутар новог контекста реалистичке књижевности. Уметничка бајка позног реализма постала је сложени конгломерат хетерогених и амбивалентних усмених жанрова, који се креће у правцу главних поетичких координата епохе - ка реалистичкој перцепцији света.Може се закључити да Илија Вукићевић, сходно главним интенцијама свог доба, логику усмене бајке подређује жанровима реалистичније књижевности, акоји се поигравају херметичним, узвишеним и митским светом традиционалне гатке. Другостепена мимеза традиционалне бајке, отворила је простор за хумористичке, ироничне и пародичне семантизације приповедног гласа, односно, за комично-пародичну дезаутоматизацију усмене бајке. Пратећи такве литерарне тенденције, све три Вукићевићеве бајке прешле су пут од канонске, до гротескно-фантастичне бајке.

\section{ЛИТЕРАТУРА}

ВУКИЋЕВИЋ, Драгана: „Српска реалистичка приповетка и бајка (типови и везе)", Зборник Матиице срӣске за језик и книжевности, 2005, год. 53, бр. 1-3, стр. 373-386.

ВУКИЋЕВИЋ, Драгана: „Српска реалистичка приповетак и фолклорна традиција", Зборник Майице срйске за језик и књиневности, 2005, год. 53, бр. 1-3, стр. 593-601.

ЖИВКОВИЋ, Драгиша: Евройски оквири срйске књижевнос$\bar{u} u$, Књ. 2, Београд, 1977.

ЖИВКОВИЋ, Драгиша: Срйска књижевносй у евройском оквиру, Београд, 2004. 
КОНСТАНТИНОВИћ, Зоран: Комйарайивно виђење срйске книжевносии и, Нови Сад, 1993.

КОНСТАНТИНОВИЋ, Зоран: Иниереиексиууална комйара-

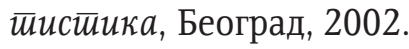

КУЛИШИћ, Ш., П. Ж. Петровић, Н. Пантић: Срйски мийолошки речник, Београд, 1970.

ЛАТКОВИЋ, Видо: Нарояна књижевности, Београд, 1967.

ЛИТИ, Макс: Евройска нароgна бајка, Београд, 1977.

МАКСИМОВИЋ, Горан: Заборављени књижевниии: књижев-

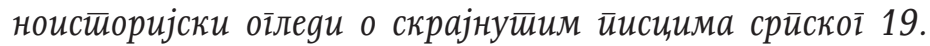
вијека, Пале, 2013.

ПРОП, Владимир: Морфолоіија бајке, Београд, 1982.

САМАРЏИЈА, Снежана: Пароgија у усменој књижевностии, Београд, 2004.

\section{ИЗВОРИ}

ВУКИЋЕВИЋ, Илија. Целокуӣна gела Илије Вукићевића. Приредио Јеремија Живановић. Београд, 1929.

Milena M. Stanković

\section{INTERTEXTUALITY AND ILIJA I. VUKIĆEVIĆ}

\section{Summary}

This paper analyses the nature of the relationship between Vukićević's literary fairy tales "The Healing Stick", "The Devil and the Girl", and "A Terrifying Dream" and genres belonging to oral literature. This interpretation shows the process of transformation of oral fairy tale within the discourse of realist literature, its adaptation within a new literary context, and its destabilization and parody. Using the intertextual approach based on the theoretical postulates by Zoran Konstantinović, the paper points to the course of development of the literary fairy tale during late 
realism, from a paradigmatic form to a grotesque and fantastic fairy tale.

Key words: Ilija Vukićević, literary fairy tale, realism, oral literature, parody, intertextual approach 